\title{
PINTAR COM ESCRIURE. UNA PASSEJADA PELS MUSEUS RIERANS
}

\author{
ANTÒNIA RAMON VILLALONGA \\ Université de Lyon 2
}

El motiu d'aquest article és la ubicació i anàlisi d'un nombre representatiu de pintures que trobam en l'obra literària de Carme Riera, les quals tracen un fil conductor a través de les dones i el paisatge. Entre les múltiples perspectives que la relació citada permet, en tractarem tres: l'ús de l'obra pictòrica com a font d'argument literari a Una primavera per a Domenico Guarini, Lassa, més t'hauria valgut i Escenarios para la felicidad; l'ús d'imatges dotades d'una significació concreta i precisa a L'estiu de l'anglès, Amb ulls americans i Temps d'una espera; i finalment l'evocació d'imatges suggerides a partir de seqüències literàries a Contra l'amor en companyia $\mathrm{i}$ La meitat de l'ànima.

PARAUles ClaU: Carme Riera, ut pictura poesis, balearització, Fernando Botero, Edward Hopper.

\section{Pintar como escribir. Un paseo por los museos rieranos}

El motivo de este artículo es la ubicación y el análisis de un número representativo de pinturas que encontramos en la obra literaria de Carme Riera, las cuales trazan un hilo conductor a través de las mujeres y el paisaje. Entre las múltiples perspectivas que la relación citada permite, trataremos tres: el uso de la obra pictórica como fuente de argumento literario en Una primavera per a Domenico Guarini, Lassa, més t'hauria valgut y Escenarios para la felicidad; el uso de imágenes dotadas de significación concreta y precisa en L'estiu de l'anglès, Amb ulls americans y Temps d'una espera; y finalmente la evocación de imágenes sugeridas a partir de secuencias literarias en Contra l'amor en companyia y La meitat de l'ànima.

PAlABRAS ClAVE: Carme Riera, ut pictura poesis, balearización, Fernando Botero, Edward Hopper.

Painting as writing. A walk through Riera's museums

This article attempts to situate and analyze a representative number of the paintings found in the literary works by Carme Riera, as they trace a recurring theme through women and the landscape. Three of the multiple perspectives that the above-cited relationship permits will be considered: the use of pictures as a source for the literary argument in Una primavera per a Domenico Guarini, Lassa, més t'hauria valgut and Escenarios para la felicidad; the use of images infused with a concrete and precise meaning in L'estiu de l'anglès, Amb ulls americans and Temps d'una espera; and finally the evocation of images suggested by the literary sequences in Contra l'amor en companyia and La meitat de l'ànima.

KEY WORDS: Carme Riera, ut pictura poesis, balearization, Fernando Botero, Edward Hopper.

Villalonga, Antònia Ramon (2013), "Pintar com escriure. Una passejada pels museus rierans", Lectora, 19: 66-80. ISSN: 1136-5781 D.O.I.: XXXXXXXXX.

Recepció: 1 de juny 2012 - Acceptació: 30 de desembre 2012 
Des que Horaci va proclamar ut pictura poesis, trobam en totes les èpoques testimonis de l'existència d'una estreta unió entre pintura i escriptura. La literatura feta per artistes plàstics i la pintura feta per escriptors omple biblioteques, il.lumina noves formes de pensament i és principi i final d'un debat secular entorn dels gèneres i la seva praxi. Conseqüentment, l'espai fronterer que es deriva de tal casament permet una gran disparitat de resultats: des de l'art total dels artistes renaixentistes fins a l'eclecticisme de Perejaume passant per la poesia plàstica de Jean Cocteau, les líricografies de Rafael Alberti o els textos teòrics de Blai Bonet. S'encabeixen en aquest mateix ordre de coses recursos i tècniques artístiques com el collage, el cal-ligrama o l'ècfrasi.

Enllà dels límits que podria imposar el gènere, Carme Riera ha explorat de manera abundant les relacions que s'estableixen entre ambdues disciplines tot al llarg de la seva obra literària. Aquesta afirmació ja se'ns revela, d'entrada, en els títols de dues de les seves novel-les: Una primavera per a Domenico Guarini de 1980 i Natura quasi morta de 2011. Fora d'ella, hem de recordar que l'autora s'ha mantingut propera a l'art plàstic en diversos escenaris. Durant els anys compresos entre 1977 i 1983, Riera va ser redactora, guionista i conductora dels programes de televisió “Tot art” (1977-1978), "Els museus” (1978-1979) i “Art Flash" (1981-1983). En la primavera de 2000 va dirigir el cicle "Mujeres que leen en la colección Thyssen-Bornemisza" en què diferents escriptors i escriptores analitzaven a partir d'una sèrie de pintures del museu madrileny la relació entre dones i lectura des del segle XVI fins al XX. Es tractava, deia Riera, de demostrar que malgrat el cúmul de circumstàncies que han impedit l'accés normal als llibres per part de les dones, aquestes han mantingut sempre un interès viu per la literatura i la cultura.

El motiu d'aquest article és la ubicació i anàlisi d'un nombre representatiu de pintures que trobam incrustades en l'obra de Carme Riera, les quals segueixen un fil conductor lligat a les dones i el paisatge. De les múltiples òptiques des de les quals es posa de manifest tal relació, en tractarem tres: l'ús de l'obra pictòrica com a font d'argument literari (Una primavera per a Domenico Guarini, Lassa, més t'hauria valgut i Escenarios para la felicidad), l'ús d'imatges amb una significació concreta i puntual (L'estiu de l'anglès, Amb ulls americans i Temps d'una espera) i finalment la suggestió d'imatges a partir de seqüències literàries (Contra l'amor en companyia i La meitat de l'ànima).

\section{Ús de l'obra pictòrica com a font d'argument literari}

A la ciutat de Florència a finals del segle XV Sandro Botticelli reprenia els temes de la mitologia grega per composar una de les al-legories més famoses a la primavera que s'ha fet al llarg de la història de l'art. "La primavera" és un quadre immens per diversos motius: per les seves dimensions espacials $(213 \mathrm{~cm} \mathrm{x}$ $314 \mathrm{~cm}$ ), per la complexitat iconogràfica de la seva composició i per les diverses claus interpretatives que se'n desprenen. El 1980 es publicava Una primavera per 
a Domenico Guarini, novel.la amb la qual Carme Riera tornava als mites clàssics així com apareixen en el llenç de Botticelli i els interpretava a partir d'una tècnica de collage pròpia de la modernitat literària.

La grandiositat física del quadre renaixentista és el terreny on comença, es desenvolupa i arriba a la fi la novel.la. A la galeria dels Uffizi un desconegut ciutadà italià que respon al nom de Domenico Guarini ha atemptat contra l'emblemàtica obra de Botticelli. La societat sencera resta commocionada, i el judici per esclarir-ne els motius

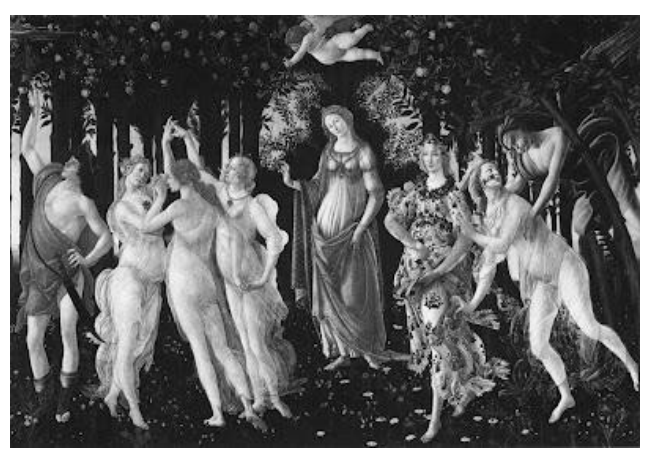
es preveu complex i tèrbol. Un diari català encomana a la mallorquina Isabel Clara Aladern cobrir-ne la notícia, fet que li permet tornar a Florència, ciutat on va viure, i reprendre històries personals que hi deixà latents. Les investigacions del cas acaben per decretar que el motiu del crim es troba justament dins el quadre, tot i que "innocent o culpable, ningú no sabrà mai quin motiu de greuge o d'amor li donaren els personatges del quadre" (Riera, 1995: 41). La sentència i resolució final del misteri, l'equilibri renaixentista, arriben amb la restauració definitiva del llenç.

La complexitat iconogràfica del quadre és equivalent a l'enfocament polièdric de cada personatge i la multiplicitat de línies argumentals. S'estableixen jocs de miralls entre els personatges narratius i els pictòrics (Isabel Clara, la periodista que ocupa el lloc central del text literari, està embarassada així com ho està la Venus, que ocupa el lloc central de la composició) i també entre els temes, els quals, com en Botticelli, giren entorn dels ideals de bellesa, amor i veritat.

El tancament de la novel.la suposa la unió definitiva entre ambdues disciplines. A la universitat s'escolta una lliçó a propòsit de les diferents metamorfosis dels personatges que habiten "La Primavera". Les explicacions són volgudament detallades, precises, i fixen el quadre en l'imaginari immediat del lector. El discurs magistral es combina amb el final de la novel-la en una espècie d'alternança dialògica, de ritme ràpid i constant, com si es tractàs d'un ball entre el mite pintat i el mite narrat.

"Lassa, més t'hauria valgut..." de 1977 apareix amb el paratext "Dedicat al pintor Roca Fuster. A imitació de 'Visió onírica d'una santa”'. Roca Fuster, amic personal de l'autora i malauradament poc recordat des de la seva mort l'any 2006, fou definit pel periodista Andreu Manresa com un "pintor literari" (Manresa, 2006) perquè historiava les seves obres amb referències de museus i llibres. El pintor creà un univers pictòric inconfusible, de personatges ingràvids, 
atmosferes oníriques i màgiques, les quals aconseguia mitjançant la superposició d'elements transparents i un tractament molt cuidat del color.

"Lassa, més t’hauria valgut..." és el primer dels versos de la cançó del segle XIV d'autor anònim "Cançó de la malmonjada". ${ }^{1}$ En ella es narra la dissort d'una jove que voldria viure en llibertat però que el destí volgué tancar-la en un convent. Riera reprèn aquest tema i tanca l'al-lota en el convent de Santa Magdalena de Palma, des d'on, en el moment concret de la narració, creu veure un bocí de la façana de casa seva. La frontera que delimita realitat i deliri es desdibuixa, talment ho fan els quadres de Roca Fuster, i els lectors no arribam a saber si la visió és real o fruit de la seva imaginació. En aquest punt de la història el cos de la jove conventual desperta, i tots els sentits es posen en funcionament de forma simultània: escolta les remors de les palmeres del jardí de la infància, sent l'olor dels sabons i perfums que ja no utilitza, nota el tacte del vestit que estrenà el dia de Carnestoltes... Per descriure el deliri de la monja, Riera recorre a l'efecte de la sinestèsia, no com a figura retòrica, sinó com a experiència del cos que consisteix a tenir sensacions d'una modalitat sensorial particular a partir dels estímuls d'una altra. Aquest recurs afavoreix la sensació de superposició i transparència a la qual ens referíem, i sobretot, a la ingravidesa del cos que perd contacte amb la terra: "Tot fou inútil. Com més et debilitaves, amb més claredat t'arribaven els colors, els perfils de les flors, els seus matisos i més feridora era la llum. El so de les campanes, l'aleteig de les tórtores, el xiuxiueig dels insectes al jardí les nits d'estiu i el batec mateix del teu cor, eren més profunds, més límpids" (Riera, 1991: 59).

Des de la reduïda cellla, la monja desplega una enorme estora màgica per la qual recorrerà els espais de la seva infància (els carrers de Ciutat, el Teatre Principal, la Portella...), geografies que recorda i estima a causa de la seva vivència personal. A "Paisatges morals. Poesia i pintura", Antoni Marí reflexiona entorn de la idea de paisatge heretada de Gaston Bachelard dins la qual hi troba amagades un conjunt d'experiències inoblidables pròpies de cada individu que fan inevitable un procés d’identificació entre les persones i la geografia.

Una experiència originària i inoblidable que possiblement tingui el seu lloc en la infantesa, on cadascú de nosaltres es podria confondre amb el riu, amb el bosc, amb el turó i amb el jardí. La natura, com a tresor de la memòria, com aquest bosc essencial que cadascú de nosaltres clou en la seva mirada, és gairebé el tresor del paradís perdut. Ja que en el fons de la nostra percepció del paisatge es conserva el record d'una mena d'experiència metafísica de la nostra identitat amb la natura. És a dir, el

\footnotetext{
${ }^{1}$ Guillermina Mota va musicar aquest poema i el va incloure en el seu disc Visca l'amor! publicat l'any 1968. Aquest disc suposa una fita indiscutible del moviment de la Nova Cançó el qual emmarca l'època en què es va escriure el conte de Carme Riera.
} 
paisatge és d'ordre metafísic i no únicament del domini físic... (Marí, 2007: 155)

Efectivament, nombrosos personatges de Carme Riera emprenen un camí de tornada cap al terreny de la infància o joventut per mirar de recuperar aquest tresor perdut. Tals espais se centren en dos redols geogràfics molt concrets que coincideixen amb la biografia personal de l'autora: Palma i els voltants de la vall de Sóller. De fet, la Mallorca evocada en els textos de Riera s'assembla més a la d'un temps que no a la de principis de segle XXI. Va ser durant la dècada dels seixanta i setanta quan la costa de l'illa es va veure dramàticament desfigurada en favor d'un creixement urbanístic desmesurat que es coneix amb el nom de balearització. ${ }^{2}$ La infància i primera adolescència de la nostra autora és d'abans d'aquesta època, de quan a l'illa no hi havia necessitat de lluitar per la preservació de la seva bellesa perquè guardava la seva fesomia natural. En el llibre Escenarios para la felicidad, publicat el 1994 per l'editorial La Foradada i inexplicablement poc citat pels estudiosos, Carme Riera ens explica com durant les seves estades a l'illa, Santiago Rusiñol i Joaquim Mir solien contemplar les postes de sol de la costa de Tramuntana esperant observar si per fortuna aparegués el mític raig verd damunt la mar. A vegades, si l'espectacle era bo aplaudien i cridaven donant gràcies a l'artífex de tal meravella. Altres, però, si l'escena no era prou satisfactòria, s'enfadaven, insultaven i fins i tot el maleïen (Riera, 1994, 64).

Santiago Rusiñol i Joaquim Mir van pintar l'illa de Mallorca de manera sublim. A l’estampa "La melancolía del paraíso" (Riera, 1994, 67-68) la mallorquina fa un breu recordatori de com els jardins han reverberat en la història de l'art en els segles XIX i XX i de com han excel-lit en l'obra de Rusiñol. En els jardins de Mallorca que pintà el català, així com els altres espais de natura, Riera hi veu un enviament al mític paradís perdut amb l'ajut i la funció dels arbres i les categories simbòliques que adopten, especialment els xiprers, pràctica de la qual també en participa el poeta palmesà Joan Alcover. En un article de 1895, Rusiñol escriu sobre els xiprers: “divagant i distraient la mirada per l'espai com per fugir de les misèries de la terra" (Riera, 1994: 67). En aquesta mateixa línia de pensament s'inscriu una reflexió de Valls a Dins el darrer blau: "L'hort no era el Paradís ni la terra de prometença, però en algun moment pensà que aquell

\footnotetext{
${ }^{2}$ Sobre el concepte balearització i les seves causes i conseqüències des del punt de vista ambiental, geogràfic i econòmic podeu llegir més informació a Macià Blàzquez, Joan Buades, Ernest Cañadas i Ivan Murray (eds.) (2011), La balearització global: conflictes socioambientals de la construcció d'hotels al Carib i a Amèrica Central, Quaderns de pau i sostenibilitat, Direcció General de Cooperació, Conselleria d’Afers Socials, Promoció i Immigració, Palma; i també a Bernat Riutort Serra i Joaquín Valdivielso Navarro (2004), "Canvi social i crisi ecològica a les Illes Balears", Les dimensions socials de la crisi ecològica, J. Valdivielso (ed.), Palma, Edicions UIB.
} 
verd de conreu, aquella frescor dels arbres, podria comparar-se-li. Un racó del món per sentir-se a pler, un redós que els emparava com l'ombra de la terra de prometença" (Riera, 2002: 377).

\section{Ús d'imatges amb una significació concreta i puntual}

El registre irònic i distanciat defineix una etapa prolífica en la carrera de l'autora on s'insereixen llibres com L'estiu de l'anglès, Amb ulls americans, Epitelis tendríssims o Contra l'amor en companyia i altres relats. ${ }^{3} \mathrm{~A}$ "Formes de la ironia en l'obra de Carme Riera", l'acadèmica Carme Gregori assenyala que, malgrat l'abundància i interès de l'autora envers el registre, els ingredients irònics de bona part de la seva obra han estat menystinguts o classificats com a "excepció o parèntesi entre les obres 'serioses' de l'escriptora" (Gregori 2012: 34) en favor d'una literatura interessada per temes com la recuperació de la memòria col-lectiva, "la construcció d'una identitat o l'ètica del discurs" (Gregori 2012: 35). En contra d'aquest supòsit, ${ }^{4}$ Gregori posa de manifest la complexitat estructural que assoleixen els jocs hipertextuals en l'obra de l'autora i que són a la base de l'estratègia irònica que vehicula el seu discurs. El quadre "La mort d'Ofèlia", que apareix en un episodi molt significatiu de L'estiu de l'anglès, serveix d'argument en el seu favor.

L'estiu de l'anglès s'inicia amb un to i una estructura fàcilment equiparables a la comèdia lleugera d'entreteniment. Això no obstant, la profusió d'elements irònics i les relacions tèrboles de les protagonistes capgiren aquest ordre de coses i encaminen l'acció narrativa cap al drama psicològic, proper a la literatura gòtica anglesa o el suspens. Laura Prat, l'agent immobiliària que marxa un estiu a Anglaterra per aprendre anglès, diu: "I encara que no tinc res en contra de la literatura ... jo pertanyo al tipus de persones que declara a les enquestes que mai no llegeix llibres" (Riera, 2006: 26). En aquestes declaracions hi veu Carme Gregori l'inici del drama personal de la protagonista, ja que amb una mínima base de cultura llibresca Laura Prat hauria reconegut trets de Norman Bates, el protagonista de Psicosis, en el comportament de la professora, o coneixeria d'antuvi els perills a què s'exposa en la solitària i emboirada pradera anglesa. Igualment nuls són els seus coneixements d'art. Un diumenge visita la Tate

\footnotetext{
${ }^{3}$ Segons Carme Gregori, una primera etapa de l'obra rierana vendria definida per una literatura intimista, confidencial i de caràcter poètic amb obres com Te deix, amor, la mar com a penyora, Jo pos per testimoni les gavines o Qüestió d'amor propi. Una tercera etapa s'emmarcaria dins el gènere de caire històric amb Dins el darrer blau, Cap al cel obert o La meitat de l'ànima. En una quarta etapa trobaríem un exercici d'exploració del gènere de la novellla negra amb Natura quasi morta. La segona etapa es definiria pel caràcter i la intenció irònica.

${ }^{4}$ Carme Gregori cita la crítica de Xavier Cortadellas (2006) a Presència en la qual diu "A L'estiu de l'anglès Carme Riera abandona la complexitat d'altres novel-les i escriu una obra menor a l'abast del gran públic, misteriosa i quasi terrorífica".
} 
Gallery amb la doble intenció de perdre de vista Mrs. Grose durant una estona i contemplar "La mort d'Ofèlia", quadre que guarda importants significacions personals:

"No volia de cap manera desaprofitar l'ocasió de visitar el museu precisament aquell dia, en què la meva mare hauria celebrat el seu vuitantè aniversari si no hagués mort l'any 2000, per contemplar en honor seu el quadre que, a ella, més li agradava del món: 'La mort d'Ofèlia' de Dante Gabriele Rossetti. Una reproducció d'aquesta pintura, procedent d'un calendari de 'la Caixa', va acompanyar-la, penjada al davant de la capçalera del seu llit, durant els darrers anys de la seva vida" (Riera, 2006: 81).

En una primera lectura, l'escena sembla servir únicament per fer avançar l'acció, però res no és gratuït en Carme Riera. L'episodi serveix a l'autora per posar en tela de judici un tipus de consum basat en l'art com a activitat turística de baix contingut intel.lectual o propagandística que fomenta una generalitzada manca de cultura artística. Irònicament, poc després del pelegrinatge de Laura Prat fins a Londres per retre homenatge a la boja ofegada més famosa de la història, el seu destí es veurà fatalment obstaculitzat pels mateixos fantasmes que impulsaren Ofèlia a llançar-se a l'aigua.

A Amb ulls americans, George Mac Gregor arriba a Barcelona empès pel seu nou amant $\mathrm{i}$ per la certesa que obtendrà una beca per escriure un treball acadèmic sobre la identitat catalana, la qual acaba de conèixer fent de figurant en un refrigeri organitzat per una delegació de la Generalitat de Catalunya a Nova York. El recurs de la mirada estrangera sobre la cultura catalana ens interessa per dos motius: primer, perquè qüestiona i desautomatitza totes les coses que va descobrint, i segon, perquè des dels seus ulls es construeix una novel.la molt visual, plena de referències pictòriques, fotogràfiques i cinematogràfiques, procedents de la fabulosa indústria de Hollywood.

El contrapunt visual català l'ofereixen les descobertes que fa l'americà del modernisme i les avantguardes de la mà de pintors com Casas, Miró, Picasso o Nonell. Casas, abans al Museu de Montserrat i després a les parets dels rics de Pedralbes, és el pintor més anomenat, tal vegada com a homenatge de l'autora a aquest bon vivant que pintava dones soles que llegien, conduïen, escrivien i feien esport. En el museu de Montserrat, bressol de la catalanitat, Gregor contempla un Casas per primera vegada: "Després de la basílica vam visitar el museu. Em va agradar molt el quadre de Casas amb una noia que fuma un havà i beu absenta" (Riera, 2009: 75). 


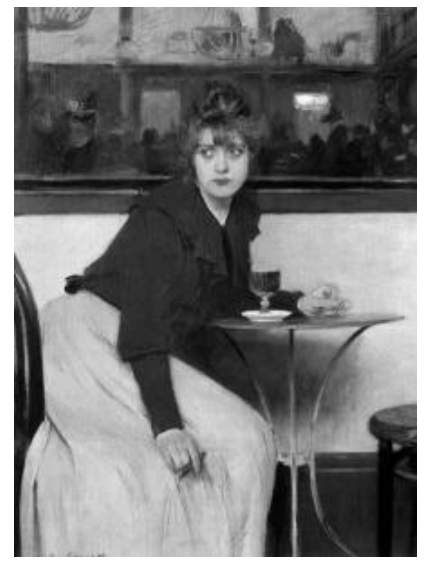

l'obra de Riera i molt versàtil.

La pintura que tant va agradar a Gregor és "Au Moulin de la Galette". ${ }^{5}$ El quadre, que recull els ambients bohemis i els coneixements pictòrics que va adquirir a París, té com a tema una dona sola, vestida de vermell, que mira quelcom que s'escapa dels límits del llenç amb un posat melangiós i reflexiu. La figura destaca sobre el reflex d'una sala de ball que es veu en el mirall del fons de la tela, a la seva esquena. Els miralls, que són una solució que ja utilitzava Velázquez per ampliar espais, obrir panorama escènic i donar una significació especial al quadre (recordem que en el mirall s'amaga la clau interpretativa de "Las Meninas"), són un element molt recurrent en

Les referències pictòriques continuen: "Els quadres de Casas em van agradar moltíssim, en especial aquell en què el far d'un cotxe projecta la llum que il.lumina l'escena, i també em va interessar un tal Alexandre de Riquer, pintor i poeta que segons Antoni, pertanyia a una antiga família catalana de l'aristocràcia, de les que ja no en queden" (Riera, 2009: 151). I finalment ens adelita una col-lecció espectacular de pintures, propietat de les famílies benestants de Pedralbes que es troben a anys llum de la Barcelona sorollosa, turística, que es ven a qualsevol preu.

Però aquesta Barcelona s'assemblava poc a la que després vaig conèixer gràcies als Forestier, i en la qual ells em feren penetrar -mai més ben dit- la Barcelona de toda la vida, com en deien, poc bullangosa, reservada, amb torres, quasi tan ben acotxades i protegides com les seves caixes fortes i on les petjades quedaven sempre amortides per les catifes d'importació, comprades en antiquaris estrangers, i per on la vista dubtava si parar-se a contemplar un Picasso de l'època blava, un cometa de Miró, una gitana de Nonell o una avantpassada pintada per Casas, obres d'art valuosíssimes que penjaven de les parets d'aquelles cases i de les quals en aparença ningú no en feia cas. Vaig comprendre fins a quin punt el silenci, la tranquil.litat i la discreció només poden ser, en bona mesura, patrimoni dels rics. (Riera, 2009: 156)

\footnotetext{
${ }^{5} \mathrm{El}$ quadre també és anomenat "Madeleine", no sabem si perquè és el nom genèric que es donava a les prostitutes o perquè la model s'anomenava Madeleine Boisguillaume. Madeleine Boisguillaume va ser una model habitual dels pintors de Montmartre, entre ells ToulouseLautrec.
} 
En el dia a dia de l'escriptura de Temps d'una espera, l'escriptora comparteix amb la filla que ha de néixer reflexions entorn de les representacions de la dona embarassada a l'art. Pel que fa a l'art religiós, Riera escriu: "No deixa de cridarme l'atenció que en la pintura religiosa es representi tan poc la figura de la Verge en estat de bona esperança i, per contra, en l'oració de l'Ave Maria es faci referència explícita 'al beneït fruit del seu ventre, Jesús”' (Riera, 1998: 41). Certament, la profusió d'obres entorn del tema cristià de l'anunciació per part de pintors de diversa procedència i època hauria pogut donar peu a un ampli tractament del cos prenyat de Maria. Contràriament, malgrat que l'àngel Gabriel fa el seu anunci en el sisè mes de gestació, els ventres voluminosos són eliminats de la composició pictòrica amb l'ajut de diversos elements aliens al cos de la dona. Com a exemple podem recordar "L'anunciació" d'Ambrogio Lorenzetti que data de 1344. En ella observam la composició tradicional del tema (l'àngel al costat esquerre i Maria al dret), un erroni joc de perspectives i dos elements summament significatius de la tradició cristiana sobre el ventre: un llibre i els braços en creu. Per altra banda, a "La visitació" de Rogier van der Weyden de 1435 s'observa una abraçada entre dues dones en evident estat de bona esperança. Explica Marie-Jo Bonnet que aquesta magnífica escena de complicitat i intimitat entre dues dones embarassades va passar totalment desapercebuda durant molt de temps a causa de la manca d'interès temàtic que suscitava (Bonnet, 2004: 98).

Les estratègies per dissimular els cossos prenys no són escasses, i això no només s'observa en la història de l'art. Una anècdota recollida en el dietari exemplifica tal pràctica de dissimular o esborrar panxes. En una conversa telefònica amb un amic diu: “Et passaré a buscar demà a les nou. Ja he reservat la taula, al V.V, com sempre. Posa't guapa, amb un vestit que dissimuli...' L'envii a passeig" (Riera, 1998: 38) —acaba sentenciant Riera. Més endavant llegim:

El cos d'una embarassada cap al novè mes és èpic, líric i dramàtic alhora, enorme i gloriós, però gens atractiu. Per això gairebé no apareixen retrats de nus d'embarassades. Els nus femenins, ja se sap, en la pintura això s'observa molt bé, s'adreçaven a adelitar els ulls masculins, objectes del desig, però sobretot - ho recorda l'estudiosa Rose Marie Bederdon, a propòsit dels nus de Susan Valendon-, accentuen la fragilitat i la passivitat del cos, com a formes del seu atractiu. (...) Record, per contra, un quadre impressionant de la pintora Alice Neel en el qual Margaret Evans posa embarassada i nua asseguda en una butaca. En primer terme se'ns ofereix un ventre enorme, pletòric de vida interior. (Riera, 1998: 181)

El 1989 el grup Guerrilla Girls de Nova York engegaren la campanya "Do women have to be naked to get into the Met. Museum". El cartell publicitari que l'encapçalava és un muntatge a partir del cos de L'Odalisca d'Ingrés, ideal de 
bellesa femenina romàntica, i el cap d'un goril.la rabiós i lleig. Amb aquesta iniciativa es pretenia arribar a un ampli públic i fer reflexionar sobre el paper de les dones en l'art: per què les dones han d'estar despullades per entrar en un museu i lluir cos jove, atractiu i virginal? Uns anys abans la pintora Alice Neel (1900-1984) marcava el camí que haurien de seguir les Guerrilla Girls. La seva obra es basa majoritàriament en retrats, individuals i collectius, com a forma d'escriure la història i deixar constància d'una determinada època. Com a feminista i brillant intel-lectual d'esquerres, Neel qüestiona molt seriosament el model de societat benestant americana: immigrants, llatins, velles, infants... són al centre de la seva obra. Posseïa una tècnica per al traç excel.lent i això li servia d'eina per aprofundir en la psicologia del personatge de manera incisiva, crua i colpidora. No només en els cossos sinó també en els gestos i les postures Neel hi troba el caràcter d'una era (Garb, 2010: 24). Coincidint amb els moviments d'alliberació de la dona dels anys seixanta i setanta, Neel dugué a terme una sèrie de set retrats de dones embarassades despullades. "We are in the midst of revolutionary changes. The madonna has been replaced by abortion and the wife and helpmate has become woman the agressor. Everything is questioned" (Allara, 1994: 7).

El quadre de què parla Riera, "Margaret Evans Pregnant", va ser pintat el 1978 i és l'últim del conjunt. La seva composició és valenta: el ventre en primer pla destaca per damunt de la resta, un cos prim, assegut, de rostre jove, boca closa, ulls oberts i posat expectant. L'ús del color accentua la quotidianitat de la imatge; les cames blaves per la retenció de líquids, els mugrons inflats preparats per alletar i els pits amb la marca del banyador. Si ens hi fixem, en el mirall de la nostra dreta (de la seva esquerra) Margaret Evans pareix més vella. És realment la mateixa persona? O és la mare que serà? El misteri del mirall i el reflex de la persona emmirallada ens connecta amb una altra cita de Temps d'una espera: "Em mir nua davant el mirall. El ventre comença a destacar-se com una mena de proa, els pits han augmentat de volum, les venes, blavoses, d'una coloració més intensa, semblen obrir més camins sota la pell tibant. De vegades em fan mal. És possible que aquest embaràs acabi amb el meu body definitivament. No és que no m'importi, m'importa i molt. Som massa jove perquè em considerin vella, però tal vegada massa vella per ser considerada jove" (Riera, 1998: 116).

Dins aquest ordre de coses, el 1966 la inclassificable Niki de Saint Phalle va dur a terme la grandiosa instal.lació Hon, que en suec vol dir "ella", en el Moderna Musee d'Estocolm. Hon era una figura femenina de 28 metres de longitud, 9 metres d'amplada i 6 metres d'alçada, en posició ajaguda, amb les cames mig obertes i estirades tot conformant un passadís que conduïa els visitants a travessar el sexe i entrar dins el ventre embarassat. La novetat de l'escultura és que constituïa un espai interior transitable i habitable (Martín, 2007: 463), concebut per dur-hi a terme tot tipus d'activitats. Així com es penetrava pel passadís cap a l'immens úter, a l'espai on tradicionalment s'hi 
col-loquen les lligacames s'hi podia llegir "Honi Soit qui Mal y Pense" amb la finalitat d'advertir a aquells que fessin una lectura errònia de la seva escultura. Els motius de tal escultura eren diversos. Uta Grosmick descriu l'interès que té l'artista des de la seva infància de crear "la major escultura de la seva generació. Més gran, més alta i més forta que la de qualsevol home" (Grosenick, 1992: 145). Per una altra banda, el retrocés vital fins al propi estat embrionari li atorgava la possibilitat de recuperar la maternitat que simbòlicament havia rebutjat vint anys enrere deixant els seus fills a Nova York per dur a terme la seva carrera artística a Europa. Es tractava d'una obra concebuda a partir de l'experiència personal, però que adquiria connotacions universals.

El tractament directe del sexe femení ens remet a una altra fita en la història de l'art. Just un segle abans d'aquesta instal-lació, Gustave Courbet havia sacsejat la benpensant acadèmia francesa amb "L'origen del món". L'obra va viure en una simbòlica clandestinitat des de la seva creació en el 1866 fins al 1995, data en què el seu darrer propietari, Jacques Lacan, la va donar al Museu d'Orsay. Desconeixem si Niki de Saint Phalle sabia de l'existència d'aquest quadre, però certament "L'origen del món" i "Hon" coincideixen tant en composició com en temàtica i podrien superposar-se formant una sola unitat. Per tant de Temps d'una espera se'n pot extreure la conclusió que "L’origen del món" és "Hon".

\section{I una conclusió personal...}

A vegades als lectors ens passa que la descripció d'un personatge, d'un escenari o d'una acció ens en recorda una altra que ja hem vist o sentit anteriorment en el context d'una disciplina diferent. Fent ús de tal concomitància artística, estroncaré les barreres del gènere i il.lustraré alguns fragments de Contra l'amor en companyia i La meitat de l'ànima amb l'obra pictòrica de dos artistes significatius del segle XX.

A "Contra l'amor en companyia", publicat dins el recull que porta el mateix títol, coneixem Coral Flora Gaudiosa, una voluptuosa escriptora de poesia eròtica que acumula quilos al mateix temps que versos des de l'exili mexicà. Després d'innumerables esforços per passar en un vestit negre de gala que hauria d'haver duit per anar a recollir un premi que tanmateix mai no guanyà, el seu cos acaba cedint a les poderoses lleis naturals: "En deu dies s'engreixà quasi vint quilos, que, sumats als que havia anat annexionant en els darrers temps, en sumaven cent tres, i, malgrat que els tenia ben repartits i la seva alçada era de metre setanta-cinc, no deixaven de ser excessius" (Riera, 1991: 67). I no és que el seu cos cedeixi, sinó que es desborda per tots els costats: "Aleshores el seu pes s'acostava als cent cinquanta quilos i li costava feina moure's. Es passava el dia gronxant-se en un balancí fet a mida, menjant dolços i esperant que qualque cosa diferent i definitiva succeís" (Riera, 1991: 72).

Fernando Botero va pintar el 1976 el quadre "La carta". Els elements que formen aquesta composició pictòrica són els mateixos que forneixen la narració 
de Riera: el cos jove, gras i bell de la protagonista que ocupa la major part de l'espai, la carta (que ometent la referència explícita del títol podríem considerar que es tracta d'uns versos acabats de confeccionar per ella mateixa), la taronja i un capteniment reflexiu. En aquest fragment Flora ha rebut una missiva anònima que la trasbalsa per la passió que se'n desprèn:

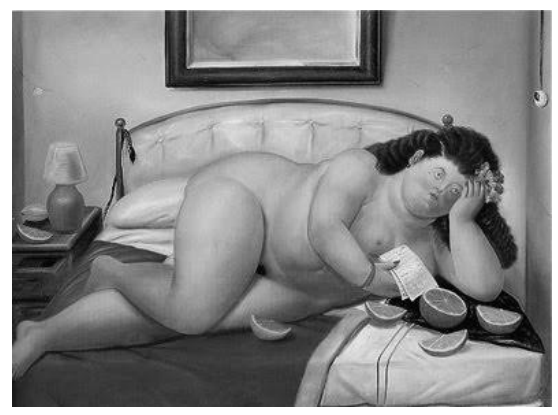

Referència:

AP: 3216

"La Carta" de Fernando Botero, 1976.

Dimensions: $149 \mathrm{~cm}$ x $194 \mathrm{~cm}$

Tècnica: Oli sobre tela

Collecció: Museo Botero, Banco de la República, Colombia

Coral Flora no volgué compartir el contingut de la carta amb els seus pares, que ben segur l'haurien feta rebutjar; menyspreà, per tant, amb aquesta decisió, les possibles pistes que ells haurien pogut donar-li i es lliurà amb fruïció a la poesia. A trenc d'alba havia compost diversos sonets lúbrics, potser una mica xerricosos pel que feia als tercets, però que en tot cas donà per vàlids. Abans d'anar-se'n a fer feina escollí el que li semblà millor i més suggeridor i l'envià a l'apartat de correus que el seu corresponsal li esmentava. (...) L'ansietat de l'espera li era doblement angoixant perquè, a l'excitació natural, calia afegir-hi la urgent necessitat de menjar que aquell estat li provocava. (Riera, 1991: 66)

L'admirador secret es descobrí: el seu editor, Martí Baixeres, quaranta anys major que ella, li proposà relacions, i poc temps després, matrimoni. Malgrat la voluptuositat eròtica que es desprenia dels seus versos, Coral arribà verge al matrimoni, i en la tan desitjada nit de noces Baixeres s'adormí tot just consumat un escàs i decebedor acte d'amor: ${ }^{6}$

Martí Baixeres complí amb els seus deures maritals amb una certa urgència i ben aviat s'adormí en els braços de la seva dona, mentre insistia que li seguís recitant les seves verduleries. Coral Flora descobrí, de sobte, a les tantes de la matinada de la seva alba de noces, que tenia la més portentosa imaginació del món, però la seva intuïció era de formiga. (...) Martí Baixeres, després de demanar-li que li declamés els

\footnotetext{
${ }^{6}$ Per llegir aquest fragment observeu "Mujer poniéndose el sujetador" de Fernando Botero, obra que data de 1970.
} 
seus versos afrodisíacs, solia quedar-se exhaust rere un únic i ràpid sisme que mai no la commovia a ella per més que habités el mateix epicentre. (Riera, 1991: 70)

Martí Baixeres morí promptament a causa de problemes de pròstata i Coral Flora, que havia viscut la sexualitat abocada en l'experiència de l'altre de manera més que insatisfactòria es descobreix nua en el mirall: ${ }^{7}$

Una nit, després d'un dia esgotador, tancada a la seva cambra, es contemplà nua en el mirall. El seu cos li recordà el de les venus rubensianes, però li semblà atractiu. "Per a ningú", pensà, estirant-se sobre el llit mentre recitava els seus antics poemes, com solia fer-ho per a Martí Baixeres. Entre versos començà a acaronar-se. Veié créixer els mugrons al contacte dels palpissos, recorregué parsimoniosament les amples cuixes, s'entretingué a desfer-se els rínxols del pubis amb dits excitats... (Riera, 1991: 73)

La meitat de l'ànima serà l'última sala que visitarem en aquesta passejada pels museus rierans, i ho farem acompanyats de l'aura del nord-americà Edward Hopper. Per parlar d'ell i de Cecília Balaguer, però, haurem de recórrer a la seva esposa Jo. Josephine Nivison havia estat una pintora d'èxit abans de conèixer el que hauria de ser el seu marit Edward Hopper. Havia exposat la seva obra al costat de Picasso i Modigliani, i la seva producció era abundant. Malgrat això, cedí tot el protagonisme a l'home quan començaren a viure junts. En el seu diari escriu: "Of course, if there can be room for only one of us, it must undoubtedly be he. I can be glad and grateful for that". Jo es convertí en la seva secretària; escrivia la correspondència, guardava memòria de cada quadre, mantenia el seu diari personal... A canvi, Hopper la perpetuava en cadascuna de les seves composicions les quals subratllaven l'aillament en què visqueren durant més de mitja vida.

El misteri que envolta la identitat de Cecília Balaguer i el seu desarrelament familiar no dista gaire del de Hopper i Josephine Nivison. A les primeres pàgines de La meitat de l'ànima descobrim la solitària protagonista en una estació de tren: "Du un abric creuat de solapes amples de color blau fosc i un barret escàs, com de circumstàncies, un barret per complir amb una moda llunyana i no amb un hivern fred com aquell del 1959. (...) Voldria posar esment en la figura d'aquesta dona que acaba de baixar d'un tren en una ciutat que no és la seva, on probablement no coneix ningú, on no sabem si ningú l'espera" (Riera, 2004: 9).

\footnotetext{
${ }^{7}$ Per llegir aquest fragment observeu "La Venus frente al espejo" de Fernando Botero de 2003. Els miralls abunden en l'obra de l'artista colombià tant en pintura com en escultura. Observeu "Mujer frente al espejo" de 1996 o l'escultura "Mujer con espejo" que es troba a la Plaza Colón de Madrid.
} 
Si ens acostam a la imatge d'aquesta dona que es troba en una cafeteria desangelada d'una estació de tren, probablement de Portbou, veurem que: "Sota els ulls d'un verd indecís, entre menta i llimonera, hi duu tatuat un cansament violeta. Però malgrat això, la bellesa del seu rostre colpeix la retina dels més observadors que, tot i la pressa, quasi s'aturen en tombar-se per tornar-se-la a mirar" (Riera, 2004: 10).

Què en sabem, d'ella? Què fa? Què pensa? Arribarem mai a conèixer la vertadera natura de la protagonista de "The Automat" (1927) i de Cecília Balaguer? La mirada de l'espectador es dirigeix cap al creuament de cames de la figura que ens traslladen a "Chair Car" (1965). Cecília-Jo, ara sense el barret escàs, es troba sola viatjant amb l'equipatge. A propòsit d'aquest, la filla escriu: "Les maletes (...) les que més a prop degueren estar del seu secret, ja que en la seva companyia va viatjar molt sovint en una època en què les dones no viatjaven i menys a l'estranger i quan ho feien era acompanyades pels marits o parents" (Riera, 2004: 31).

Cecília viatja sola a París molt sovint per visitar el seu pare i trobar-se amb l'home que vertaderament estima. A ell li escriu cartes on s'hi abandona amb la passió més absoluta:

T'estic esperant a la nostra cambra. M'agrada arribar abans que tu. M'agrada assaborir aquests minuts - però no tardis, amor, no t'entretenguis- d'espera, de vespera de goig. No m'importa que l'encarregada de l'E. em miri amb certa sornegueria: el senyor no ha arribat encara... Sóc jo la que ha vingut abans d'hora. I és cert. He sortit de casa amb molt de temps per endavant per assaborir tots els minuts que m'acosten a tu, ben a plaer, amb parsimònia. (Riera, 2004: 58)

Javier Goñi destaca que en el lluminós "Morning Sun" (1952) Hopper experimenta amb la incidència de la llum solar sobre el cos de la dona, la qual resta impassible, quasi indefensa davant el finestral. La claredat del cel i els rajos del sol entren sense recança i accentuen una sensació d'inquietud i espera (Goñi, 2005: 50). Continua essent la Cecília-Jo inaccessible, misteriosa, que espera quelcom que ha d'arribar.

Però el seu no és un amor reeixit en la mesura que hauria volgut, $i$ a les escenes d'esperança i llum d'abans de la trobada, en segueixen unes altres de desolació, tristesa i tancament. La filla recorda el capteniment de Cecília:

La meva anada a París fou del tot inútil perquè ell no em va voler conèixer i el vestit més polit, de vellut blau amb una gran llaçada de moaré a la cintura, que la meva mare havia dipositat amb tota cura dins la meva maleta, probablement perquè me'l posés per anar al seu encontre, es va quedar, durant les dues setmanes de la nostra estada, penjat a l'armari de l'habitació que jo vaig ocupar. (...) No sé tampoc si 
ells arribaren a trobar-se, ni si l'home que esperava ma mare aquella nit vora el portal i que jo vaig veure des de la finestra era ell. (Riera, 2004: 48)

"Hotel Room" (1931) suposa una síntesi de l’univers de Hopper. Cecília-Jo mig despullada resta abatuda en el llit d'una habitació de pas mentre llegeix una carta. Probablement la mirada indefinida i fosca n'oculta les llàgrimes. Les maletes i el barret escàs que l'han acompanyat durant tot el viatge són al fons, i la finestra per on una estona abans entrava la llum del dia ara és opaca. L'aire desolat de l'habitació reflecteix l'interior de la protagonista, desencisada pel menyspreu de l'amant.

Fet aquest recorregut pictòric, queda de manifest fins a quin punt l'autora trenca les convencions del gènere $i$ fa que literatura $i$ arts plàstiques siguin dues disciplines vertaderament pròximes. D'altra banda, hem afegit arguments per bastir la crítica que llegeix l'obra rierana des de l'òptica feminista i de defensa del paisatge. Per acabar ens cal afegir que a aquestes tres vies d'aproximació a la pintura en l'obra de la mallorquina se n'hi poden sumar d'altres, dins alguna de les quals hi encaixaríem Natura quasi morta, que agermana el gènere de la novel.la negra al de les natures mortes plàstiques.

\section{REFERÈNCIES BIBLIOGRÀFIQUES}

Allara, Pamela (1994), “Mater' of fact: Alice Neel's pregnant nudes”, American Art, 8: 6-31.

Bonnet, Marie-Jo (2004), Les femmes dans l'art, París, La Martinière.

Garb, Tamar (2010), “The human race torn to pieces", Painted Truths: The Painted Portraits of Alice Neel, Jeremy Wilson i Barry Walker (eds.), Houston, Museum of Fine Arts.

Goñi, Javier (2005), Edward Hopper. Grandes genios del arte contemporáneo, Madrid, El siglo XX-Unidad editorial.

Gregori, Carme (2012), "Formes de la ironia en l'obra de Carme Riera", Els subjectes de l'alteritat. Estudis sobre la narrativa de Carme Riera, Pilar Arnau i Luisa Cotoner (eds.), Palma, Institut d'Estudis Baleàrics i Publicacions de l'Abadia de Montserrat.

Manresa, Andreu (2006), “Joan Miquel Roca Fuster, pintor”, El País, 04/07/2006. 30/5/2012.

<http://elpais.com/diario/2006/07/04/agenda/1151964007_850215.html>

Marí, Antoni (2007), "Paisatges morals. Poesia i pintura", Arts de poeta, Jordi Julià i Pere Ballart (eds.), Palma, Lleonard Muntaner.

Riera, Carme (1995), Una primavera per a Domenico Guarini, Edició especial per l'Avui, Barcelona, Edicions 62. [1980]. 
-(1991) "Lassa, més t'hauria valgut...", Contra l'amor en companyia $i$ altres relats, Barcelona, Destino.

-(1994) Escenarios para la felicidad. Estampas de Mallorca, Palma, La Foradada.

-(2006) L'estiu de l'anglès, Barcelona, Proa.

-(2009) Amb ulls americans, Barcelona, Proa.

-(1998) Temps d'una espera, Barcelona, Columna.

-(1991) "Contra l'amor en compañía", Contra l'amor en companyia $i$ altres relats, Barcelona, Destino.

-(2004) La meitat de l'ànima, Barcelona, Proa.

-(2011) Natura quasi morta, Barcelona, Edicions 62. 